Dominika Jagielska

Uniwersytet Jagielloński

\title{
KSZTALCENIE CHARAKTERU A ODRODZENIE NARODU POLSKIEGO - KONCEPCJA WYCHOWANIA DO niepodległości Jana Ciemniewskiego (NA PODSTAWIE TWÓRCZOŚCI DO 1918 ROKU)
}

[The shaping of character and the rebirth of the Polish nation - Jan Ciemniewski's concept of education for independence (based on the works until 1918)]

S u $\mathrm{m} m$ ary: In this article I examine the issue of education for independence, which appears in the early work of Jan Ciemniewski. In particular, I focus on the relationships which according to him exist between character education and the rebirth of Polish independence. I also present his project for building the freedom and greatness of an independent Poland.

Keywords: character education, education for independence, Jan Ciemniewski, pedagogy of culture

\section{Wprowadzenie}

„Historia magistra vitae est”, jak mawiali starożytni, zwracając uwagę na to, jak wiele dla teraźniejszości i przyszłości może znaczyć poznanie naszej przeszłości. Chociaż współcześnie taka myśl w potocznym ujęciu staje się coraz mniej popularna - liczy się głównie to, co tu i teraz - to jednak świat akademicki nie może zapomnieć o znaczeniu tego, co przeszłe, co stanowi podstawę naszego myślenia i działania, może wnosić nowe, interesujące wątki w diagnozę oraz analizę dzisiejszej rzeczywistości, a także pomagać w ocenie nowych idei, różnorodnych koncepcji teoretycznych i praktycznych. Nauka powinna zatem odkrywać i przypominać różne teorie, koncepcje, hipotezy, pomysły, sposoby interpretacji świata, które stworzyli nasi przodkowie, co oznacza konieczność skierowania wysiłku badawczego jej przedstawicieli nie tylko na poszukiwanie odpowiedzi na pytania współczesności i przyszłości, ale również uznanie znaczenia pogłębionej pracy wkładanej $\mathrm{w}$ poszukiwanie przeszłości nieodkrytej, może dawniej lub obecnie niedocenianej, z różnych powodów ukrytej lub zapomnianej. 
W pedagogice takich „białych plam”1 do odkrycia i zaprezentowania społeczności naukowej jako jednego ze źródeł myślenia i działania pedagogicznego jest jeszcze wiele, a polska myśl pedagogiczna nie zawsze pozostaje czy pozostawała rozpoznana lub też doceniana zarówno przez współczesnych, jak i potomnych. Tym bardziej w związku z możliwościami, jakie otwierają się przed pedagogami współcześnie, zaczyna się rysować potrzeba uważnego, analitycznego i zarazem krytycznego przeglądu mniej lub bardziej odległych w czasie propozycji różnych myślicieli i pedagogów, jakie były przez nich wysuwane $\mathrm{w}$ obszarze wychowania. Może to pomóc pedagogom poznać siebie i swoją dyscyplinę jeszcze lepiej, skłaniać do refleksji teoretycznej i zmian w obszarze praktyki pedagogicznej.

W polskiej myśli pedagogicznej w 1945 roku nastąpiło zerwanie ciągłości refleksji nad wychowaniem - koncepcje katolickie, tomistyczne i personalistyczne, obecne w polskiej myśli pedagogicznej dwudziestolecia międzywojennego, ze względu na specyfikę polskiej historii powojennej zostały zapomniane lub odrzucone, a powrót do nich stał się możliwy dopiero, gdy zaszły przemiany społeczno-ustrojowe ${ }^{2}$. Chociaż koncepcje te mogą być współcześnie różnie oceniane, nie można im odmówić, zarówno w przeszłości, jak i współcześnie, wpływu na losy naszego narodu i państwa oraz istotnego znaczenia dla teoretycznych podstaw pedagogiki ${ }^{3}$ oraz dla praktycznej działalności wychowawczej ${ }^{4}$.

Jedną z takich koncepcji - jak myślę, wartych uwagi - której krótkiej rekonstrukcji i analizy pragnę dokonać $\mathrm{w}$ niniejszym artykule, jest myśl pedagogiczna Jana Ciemniewskiego. Ten ksiądz katolicki, publicysta i prężnie działający pedagog żył w latach 1866-1947. Doktorat z filozofii uzyskał

\footnotetext{
${ }^{1}$ Po raz pierwszy po 1989 roku zaczęto mówić o nich oraz konieczności ich odkrywania już na pierwszym Zjeździe Pedagogicznym. Zob. Ewolucja tożsamości pedagogiki, H. Kwiatkowska (red.), Warszawa 1994.

${ }^{2}$ Por. J. Kostkiewicz, Kierunki i koncepcje pedagogiki katolickiej w Polsce 1918-1939, Kraków 2013, s. 13-16.

${ }^{3}$ Por. tamże, K. Kalka, Fïlozoficzna antropologia tomistyczna okresu międzywojennego $w$ Polsce jako podstawa ksztaltowania charakteru, Bydgoszcz 2000; Pedagogika katolicka. Zagadnienia wybrane, A. Rynio (red.) Stalowa Wola 1999; E. Walewander, Wychowanie chrześcijańskie w nauczaniu i praktyce Kościoła katolickiego, Lublin 1996.

${ }^{4}$ Por. W. Theiss, Katolicka praca społeczno-wychowawcza. Szkic zagadnienia, w: „Pedagogika społeczna" 2013, 2, s. 47-71; E. Walewander, Wychowanie chrześcijańskie w nauczaniu i praktyce, dz. cyt.; ks. Z. Babicki, Społeczno-wychowawcza działalność Księży Pallotynów w Polsce, Ząbki 2009; Jestem wychowawca. Model pracy $z$ uczeniem $i$ klasa szkolnq wedhug systemu prewencyjnego Jana Bosko, K. Franczak (red.), Warszawa 2004; ks. J. Niewęgłowski, Wychowawczo-spoleczna działalność salezjanów w Polsce $w$ latach 1898-1989, Warszawa 2011; Pedagogie katolickich zgromadzeń zakonnych. Historia i wspótczesność, t. 1, J. Kostkiewicz (red.), Kraków 2012; Pedagogie katolickich zgromadzeń zakonnych. Historia i wspótczesność, t. 2, J. Kostkiewicz, K. Misiaszek (red.), Kraków 2013; Pedagogie katolickich zgromadzeń zakonnych. Historia i wspótczesność, t. 3, J. Kostkiewicz (red.), Kraków 2015.
} 
w Uniwersytecie Gregoriańskim w Rzymie, studiował również w Uniwersytecie Katolickim w Paryżu. Jakiś czas pracował jako wykładowca etyki w Detroit, pełnił funkcję proboszcza w Trenton (stan New Jersey), ale w 1896 roku powrócił na ziemie polskie. Pracował jako katecheta (Stanisławów, Tarnopol, Lwów), a swoją działalność społeczną związał przede wszystkim z walką $\mathrm{z}$ alkoholizmem (był założycielem Polskiej Ligi Przeciwalkoholowej we Lwowie) oraz członkostwem w organizacjach podejmujących działania o charakterze narodowo-społecznym ${ }^{5}$. Jego twórczość łączy teoretyczne opracowania pedagogiczne skupiające się na koncepcji wychowania charakteru człowieka z szeroko zakrojonymi analizami społecznymi oraz historycznymi koncentrującymi się wokół fenomenu narodu, zwłaszcza narodu polskiego, oraz jego cech charakterystycznych. Opracowania dorobku Jana Ciemniewskiego z późniejszego okresu jego twórczości - dwudziestolecia międzywojennego - dokonała Janina Kostkiewicz, klasyfikując jego dzieła z tego czasu jako przynależne do katolickiego nurtu pedagogiki kultury ${ }^{6}$. W niniejszym artykule zajmuję się jego wcześniejszymi i najistotniejszymi dziełami o charakterze pedagogicznym powstałymi i opublikowanymi do roku 1918. Stanowią one podstawę jego późniejszych dokonań. W sposób szczególny koncentruję się na związkach, jakie według Jana Ciemniewskiego zachodzą pomiędzy wychowaniem i kształceniem człowieka a odzyskaniem przez Polskę niepodległości oraz na przedstawianym przez niego projekcie budowania wolności i wielkości mającego odrodzić się państwa polskiego, ponieważ te kwestie wydają się leżeć w centrum jego myśli społecznej i pedagogicznej.

\section{Pojęcie charakteru jako podstawowa kategoria koncepcji pedagogicznej Jana Ciemniewskiego}

Rozpocząć należy od wyjaśnień, czym dla Jana Ciemniewskiego jest charakter, ponieważ ten fenomen jest podstawową kategorią pedagogiczną jego koncepcji. Pojęcie to $\mathrm{w}$ myśli tego autora ma podwójne znaczenie. W pierwszym, szerokim rozumieniu traktuje on charakter jako określenie indywidualnych cech człowieka, zarówno jego duszy, jak i ciała: rozumu, woli, uczucia i temperamentu, wyglądu; jest to charakterystyczny dla konkretnej jednostki sposób myślenia, pragnienia, działania, czucia. $\mathrm{Z}$ tej perspektywy każdy ma określony charakter. W szerszym, nieścisłym ujęciu charakter według Ciemniewskiego - to właściwie to samo co temperament, przez który

${ }^{5}$ Zob. Ciemniewski Jan, w: Stownik Pedagogów Polskich, W. Bobrowska-Nowak, D. Drynda (red.), Katowice 1998, s. 39-40; J. Kostkiewicz, Kierunki i koncepcje pedagogiki ..., dz. cyt., s. 207.

${ }^{6}$ Zob. tamże, s. 207-234. 
rozumiał on pewne wrodzone lub indywidualne skłonności czy właściwości organizmu każdego człowieka ${ }^{7}$. Pojęcie charakteru obejmuje zatem całego człowieka i jego właściwości, akcentując jego indywidualność oraz wyjątkowość.

Jednak bardziej istotne dla Jana Ciemniewskiego wydaje się drugie, jak pisze - ścisłe - znaczenie tego pojęcia, w którym charakter odnosi on do moralnych cnót człowieka, a szczególnie do jego wyćwiczonej i zahartowanej woli. Jego posiadanie wiąże się $\mathrm{z}$ wprowadzeniem $\mathrm{w}$ życie (zinternalizowaniem, a potem adekwatnym i konsekwentnym eksternalizowaniem) przez daną osobę wartości i norm porządku społecznego, pewnej harmonii i zgodności z obowiązującymi prawami. Jest związane również z właściwym używaniem rozsądku i sumienia w relacjach z innymi ludźmi, panowaniem nad własnymi instynktami i uczuciami, myślami oraz czynami. Wszystko to składa się na pewną stałość i sprawiedliwość postępowania człowieka, pomimo zmian i pokus wyrastających z otaczającej go rzeczywistości społecznej. Tak rozumiany charakter nie jest jednak dla Ciemniewskiego czymś stałym i niezmiennym; jest właściwością nabytą, zatem znajduje się cały czas $\mathrm{w}$ stanie tworzenia, doskonalenia, utwierdzania ${ }^{8}$ - ,jest wynikiem pracy i walki życiowej”, w nich się kreuje oraz potwierdza. Te dwa sposoby interpretacji charakteru przeplatają się między sobą w twórczości Jana Ciemniewskiego, który sięga po jedno lub drugie w zależności od potrzeb i kontekstu wywodu. Niemniej jednak podkreśla szczególnie rolę charakteru $\mathrm{w}$ rozumieniu zbioru cnót moralnych jako najważniejszego czynnika, od którego zależy przyszłość całego narodu polskiego.

Rozważając fenomen charakteru Jan Ciemniewski wskazuje, że „obejmuje [on - dop. D.J.] przeto całego człowieka, a więc zarówno popędy, uczucia i przyrodzone skłonności, jak rozum i wolę, które rozwijają się stopniowo, w miarę pracy i wysiłków każdego" ${ }^{10}$. Zwraca zatem uwagę na dwie istotne kwestie: po pierwsze, na istnienie różnych elementów charakteru, dla których koniecznością jest harmonijne współdziałanie, tworzące całość; po drugie, na potencjalną i otwartą naturę charakteru, konieczność jego wypracowywania, włożenia osobistego wysiłku w jego kształtowanie. Z perspektywy pedagogicznej ważne jest podkreślenie, że tym samym wydaje się on nie odróżniać wysiłku inspirowanego z zewnątrz, kierowanego przez wychowawcę, oraz takiego, który jest samodzielnie podejmowany przez osobę.

\footnotetext{
${ }^{7}$ J. Ciemniewski, Poznanie i kształcenie charakteru, cz. I, Lwów 1903, s. 25-30.

${ }^{8}$ Tamże, s. 25-28.

${ }^{9}$ Tamże, s. 5-6.

${ }^{10}$ Tamże, s. 129.
} 
Oznacza to uznanie przez tego myśliciela istotnego znaczenia zarówno wychowania, jak i samowychowania dla procesu kształtowania charakteru.

Do elementów, z których według Jana Ciemniewskiego składa się charakter, należą: instynkt, uczucia, rozum oraz wola, a także sumienie, rozumiane przez niego jako „świadomość godziwości lub niegodziwości danego postępku"11. Pierwsza ze składowych, instynkt, jest niższą władzą człowieka. To nieświadomy popęd, bezwiedne postępowanie dążące do zachowania zdrowia i życia jednostki lub całego gatunku. Jest zatem podstawą istnienia zarówno rodzaju ludzkiego, jak i poszczególnych jednostek - dzięki niemu możemy trwać $\mathrm{w}$ świecie. Jednak równocześnie instynkt jest według Ciemniewskiego przyczyną wielu złych zjawisk w życiu jednostek i społeczeństw, między innymi źródłem różnego rodzaju niepowodzeń społecznych. Uważa on go bowiem za siłę ślepą, nieracjonalną oraz bezwzględną, zdążającą do celu bez oglądania się na kogokolwiek i cokolwiek ${ }^{12}$, a zwłaszcza na rozum czy wolę opartą na poznaniu. Człowiek działający instynktownie nie kieruje się moralnością a jedynie własnymi potrzebami, popędami czy interesami - staje się zatem najgorszego rodzaju egoistą. Dlatego też ta władza musi być poddawana ścisłej kontroli przez każdego człowieka - jest to możliwe dzięki wyćwiczonemu rozumowi i woli.

Za podstawę charakteru uważa zatem Jan Ciemniewski moralność, którą interpretuje jako umiejętność panowania nad popędami w ten sposób, że bierze się pod uwagę innego człowieka, jego potrzeby i prawa, nie dając sobie prawa do jego krzywdzenia, a równocześnie wypełnia się wszelkie swoje obowiązki i powinności. Aby możliwe było moralne postępowanie, potrzebna jest potęga woli, a także ducha człowieka, która jest możliwa do wypracowania - rodzi się w wysiłkach, jakie wkładamy w panowanie nad instynktami ${ }^{13}$. Jak podkreśla Jan Ciemniewski „w tem tkwi wielkość i godność człowieka. Wyemancypowanie się z pod samolubnej władzy instynktu, opanowanie żądz swoich i zdobycie władzy nad sobą" ${ }^{14}$. Zaznacza również, że „charakter ludzki tam dopiero się pojawia, gdzie zaczyna się budzić samowiedza i gdzie wola poczyna działać i panować nad instynktem" ". Sam instynkt nie jest więc wystarczający dla osiągnięcia pełni człowieczeństwa wyrażającej się w silnym, stałym charakterze. Ważne wydaje się tu twierdzenie o samowiedzy jako podstawie powstawania charakteru - jego kształtowanie jest zatem procesem długotrwałym, rozciągniętym $\mathrm{w}$ czasie, a sam charakter $\mathrm{w}$ drugim ze wskazywanych przez Ciemniewskiego znaczeń pojawia się $\mathrm{w}$ związku

\footnotetext{
${ }^{11}$ Tamże, s. 129.

12 Tamże, s. 45-48.

${ }^{13}$ Tamże, s. 56-62.

${ }^{14}$ Tamże, s. 63 .

${ }^{15}$ Tamże, s. 129.
} 
z rozwojem poznawczym człowieka i wiąże się z jego funkcjonowaniem społecznym.

Dla panowania nad instynktem niezbędne są wola i rozum, kolejne składniki charakteru ludzkiego. Obie te władze człowieka w koncepcji Ciemniewskiego współdziałają - nie można bowiem niczego chcieć bez poznania: wyobrażenia będące wyrazem rozumu budzą pożądania stanowiące obiekty woli. Wola jest władzą człowieka pożądającą dobra ogólnego, które według Ciemniewskiego jest prawdą, pięknem i dobrem. Ale jej działanie jest możliwe tylko dzięki poznaniu umysłowemu - dzięki wyobrażeniom podsuwanym przez rozum, które stają się potencjalnymi przedmiotami pożądania ${ }^{16}$. To poznanie umysłowe zatem, poprzez podsuwanie woli różnego rodzaju wyobrażeń rzeczy lub idei, pobudza ją do działania, dzięki niemu wola „odkrywa” to, ku czemu może i pragnie się kierować.

Rozum i dokonywane dzięki niemu poznanie umysłowe wprowadzają do duszy człowieka więcej idei i wyobrażeń niż pierwsze instynkty, uczucia i wyobraźnia ${ }^{17}$ (których przewaga jest charakterystyczna zwłaszcza dla okresu wczesnego dzieciństwa). Jak się zatem wydaje, dla Ciemniewskiego poznanie nie jest związane jedynie z działaniem rozumu, ale dotyczy również wrażeń dostarczanych przez zmysły, co jest charakterystyczne dla tomistycznej wykładni epistemologii ${ }^{18}$. To jednak dzięki rozumowi możliwe jest poznanie wyższych wartości i idei, motywów dostarczających wyższych pobudek do działania woli, do których Jan Ciemniewski zalicza między innymi: honor, wiedzę, miłość do ojczyzny, sprawiedliwość, obowiązek. Zatem rolą rozumu jest tworzenie w umyśle ludzkim takich idei, które przekładają się na chcenie tego, co dobre i szlachetne. Dlatego według Ciemniewskiego potrzebne jest rozpoznanie prawd i ideałów, wyznaczenie jasnych motywów i zasad działania dla właściwego używania woli, co jest możliwe dzięki poznaniu rozumowemu ${ }^{19}$. Jeśli bowiem idee powstające $\mathrm{w}$ nas dzięki poznaniu umysłowemu będą kierowały się ku dobru, pięknu i prawdzie, to wola człowieka będzie bardziej skłonna te wartości realizować.

Rozum jest zatem niezwykle ważną władzą człowieka - właściwe jego używanie prowadzi do samodoskonalenia, a jego najpotężniejszą bronią według Jana Ciemniewskiego są skupienie, uwaga i refleksja nad sobą. Ich brak tworzy lukę, przez którą do umysłu człowieka może wślizgnąć się zło $\mathrm{w}$ postaci sprzyjania instynktom lub opanowania umysłu przez uczucie ${ }^{20}$.

\footnotetext{
${ }^{16}$ Tamże, s. 131 .

${ }^{17}$ Tamże, s. 137 .

${ }^{18}$ Por. G.L. Gutek, Filozoficzne i ideologiczne podstawy edukacji, Gdańsk 2003, s. 59-6o.

${ }^{19}$ J. Ciemniewski, Poznanie i ksztatcenie charakteru, cz. I, dz. cyt., s. 135-137, 141.

${ }^{20}$ Tamże, s. 141.
} 
„Panowanie nad sobą i siła woli zawisła tedy od umiejętności skupienia naszej uwagi na pewnych zasadniczych prawdach, przed któremi ustąpić muszą wszelkie porywy i zachcianki instynktu, wszelkie wymówki i kaprysy, wyobrażenia lub uczucia. Tylko $\mathrm{w}$ ten sposób można osiągnąć silną wolę i panowanie nad namiętnościami, czyli wyrobić $\mathrm{w}$ sobie silny i stały charakter" ${ }^{21}$. Rozum wyznacza zatem człowiekowi podstawowy cel życia a może nim być według Jana Ciemniewskiego jedynie dobro najwyższe i bezwzględna, jedyna prawda, które realizują się w Bogu. Celem istnienia człowieka może być tylko Bóg, który jest doskonałością - wypełnianie celu życiowego jest zatem ciągłym dążeniem człowieka do doskonałości ${ }^{22}$. Tak określony cel życia człowieka wydaje się równocześnie najprostszym i najbardziej logicznym motywem podejmowania działalności wychowawczej, która w pierwszych etapach życia każdej osoby wspomaga ją w próbach osiągania coraz większej bliskości z Bogiem.

Jak się wydaje, takie podejście Ciemniewskiego do celu życiowego każdego człowieka wynika z przyjmowania przez niego jako punktu wyjścia do analizy człowieka założeń św. Tomasza z Akwinu ${ }^{23}$, która Boga uznaje za przyczynę sprawczą świata i jednocześnie cel jego istnienia ${ }^{24}$. Skoro zaś istnienie Absolutu jest koniecznością dla wyjaśnienia świata, to jego poznanie wydaje się ważnym i koniecznym warunkiem życia człowieka, które z kolei prowadzi do podporządkowania się prawu boskiemu i dążeniu ku Bogu. Ujęcie Boga jako podstawowego celu życia każdego człowieka wydaje się również charakterystyczne dla katolickich koncepcji pedagogicznych dwudziestolecia międzywojennego bazujących na tomistycznym ujęciu człowieka ${ }^{25}$.

Wola - kolejny element charakteru według Jana Ciemniewskiego - to taka władza, która działa pod wpływem racjonalnych (rozumowych) pobudek, ale jej podstawową właściwością jest wolność, a nie konieczność. Chęć jest zatem wolna, to znaczy, że trudno przymusić ją do działania, którego nie chce podjąć. Ogólnie rzecz ujmując, Ciemniewski uważa wolę za przyczynę czynu,

\footnotetext{
${ }^{21}$ Tamże, s. 139.

${ }^{22}$ Tamże, s. 153 .

${ }^{23}$ Należy zauważyć, że jego twórczość, również ta, którą określam tu jako wczesną, przypada już przypada już po ogłoszeniu encykliki Aeterni Patris (1879), która określa tomizm jako filozofię reprezentatywną dla katolicyzmu oraz zachęca do jej ponownego odczytania i twórczej reinterpretacji. Skoro zaś Ciemniewski studiował w Rzymie i Paryżu, musiał się zetknąć z zarówno klasyczną wersją tomizmu, jak i współczesnymi mu odczytaniami tej myśli. Por. Leon XIII, Encyklika Aeterni Patris o studiach filozoficznych, Warszawa 1902; J. Kostkiewicz, Kierunki i koncepcje ..., dz. cyt., s. 180-182.

${ }^{24}$ Por. A. Maryniarczyk, Dlaczego tomizm dziś?, w: „Człowiek w kulturze” 1994, nr 2, s. 155-156.

25 Przykładowo Jacka Woronieckiego. Zob. J. Kostkiewicz, Kierunki i koncepcje ..., dz. cyt., s. 105-107.
} 
która - używana należycie - pragnie piękna, dobra i prawdy ${ }^{26}$. Warto tu zauważyć, że w jego koncepcji wola (odpowiednio wyćwiczona) prawdopodobnie nie tylko realizuje dobro, ale również pragnie poznania przez rozum prawdy i piękna, oddziałuje więc na rozum i kieruje poznanie ku tym wartościom. Można zatem uznać, że w procesie kształcenia charakteru zachodzi tu sprzężenie zwrotne pomiędzy rozumem i wolą jako najważniejszymi władzami człowieka.

Wola jest dla niego przyczyną każdego ludzkiego działania, ponieważ nie jest ono determinowane mechanicznie (jak zjawiska fizyczne w naturze), ale podejmowane w sposób niezależny i niekonieczny - człowiek dzięki woli może podjąć działanie lub go zaniechać, zmieniać świat, realizować ideały ${ }^{27}$. Wolność staje się zatem u Ciemniewskiego podstawową charakterystyką woli.

Jest to władza niezwykle istotna z punktu widzenia tego myśliciela. Jak bowiem twierdzi: „wola nadaje myślom i uczuciom, czynom i przyzwyczajeniom człowieka pewien samodzielny kierunek, tworząc $\mathrm{w}$ nim w ten sposób nowy, niezależny charakter moralny, który tem jest doskonalszy, im mniej odbiega do pierwotnego ideału i prototypu swego"28. Potwierdza to zatem wniosek o pozostawianiu woli we wzajemnej zależności z rozumem człowieka. Poza tym, jak podkreśla Ciemniewski „wola ochocza i czynna największe nawet pokona trudności. Nie tylko władze duchowe, jak rozum, słuchają jej rozkazów, ale podlegają jej nawet niektóre funkcje fizyologiczne. (...) W woli przeto szukać należy początku i końca charakteru człowieka. W woli bowiem tkwi energia, która jest siłą twórczą charakteru, z woli płynie gorliwość i zapał do pracy, która powoli krystalizuje w nas jaźń duchową, w woli leży spokój i pogoda ducha, umiejąca wszystko widzieć w dobrem świetle, w woli spoczywa lagodność i przyjacielskie usposobienie dla bliźnich, w woli kryje się zdolność zaparcia i poświęcania się dla bliźnich, w woli również mieści się odwaga nieustraszona, nieugiętość przekonań, cierpliwość w przeciwnościach, wytrwałość w walce, wreszcie bohaterska śmierć w obronie idei!"29.

Co ważne, wola tworzy w człowieku „jaźń duchową”, jest podstawą charakteru moralnego człowieka - dobrze realizowana wypracowuje bowiem podporządkowanie prawu, obowiązkowi oraz sumieniu i sama $\mathrm{z}$ tego podporządkowania wyrasta. $\mathrm{W}$ takim ujęciu wydaje się zatem najważniejszą władzą z perspektywy jego rozwoju moralnego oraz społecznego, chociaż niemożliwą do realizacji bez łączności z pozostałymi.

\footnotetext{
${ }^{26}$ J. Ciemniewski, Poznanie i kształcenie charakteru, cz. I, dz. cyt., s. 61, 162.

${ }^{27}$ Tamże, s. 61, 162.

${ }^{28}$ Tamże, s. 163 .

${ }^{29}$ Tamże, s. $164-165$.
} 
Ostatnią $\mathrm{z}$ części składowych charakteru $\mathrm{w}$ koncepcji Jana Ciemniewskiego jest uczucie, któremu to przypisuje on ogromne znaczenie. Definiuje je jako „przykry lub przyjemny stan duszy, wywołany odpowiedniem lub nieodpowiedniem podrażnieniem. Stany te nazywamy uczuciem, bo w nich dusza sama siebie odczuwa i poznaje" ${ }^{30}$. Według niego uczucie ożywia całego człowieka, intensyfikuje działanie wszystkich władz, może więc służyć uszlachetnieniu człowieka. Ale nadaje również rozumowi kierunek, co może doprowadzić go na manowce, jeśli człowiek nie nauczył się i nie wyćwiczył panowania nad uczuciami ${ }^{31}$. Uczucie bowiem, przez Ciemniewskiego określane również jako serce, ma niezwykłą moc, dzięki której może zyskać przewagę zarówno nad rozumem, jak i nad wolą człowieka, który przezeń zostały opanowany. Brak panowania nad uczuciami prowadzi zatem do podobnych efektów jak niemożność zapanowania nad swoimi instynktami człowiek opanowany przez jedno lub drugie wyrzeka się części swego człowieczeństwa.

Dla Jana Ciemniewskiego ideałem człowieka jest taka osoba, która posiada bystry, wyćwiczony przez pracę intelektualną i wykształcenie rozum, wytrwałą i czynną wolę oraz szlachetne, miłosierne serce ${ }^{32}$. Osiągnięcie tych właściwości jest kwestią pracy nad wszystkimi składowymi charakteru, wysiłku i ćwiczenia - jest zatem potencjalnie osiągalne dla każdego człowieka, jeśli tylko będzie on ukierunkowany na najważniejsze wartości moralne. Jak podkreśla Ciemniewski, „charakter - to rzecz najcenniejsza na świecie; praca nad jego uszlachetnieniem - to najświętszy obowiązek każdego człowieka” ${ }^{\text {33 }}$.

Zagadnienie charakteru i jego elementów składowych jest jednym $\mathrm{z}$ tych, które można odnaleźć w twórczości Jan Ciemniewskiego, a które stanowi ważne wprowadzenie do koncepcji wychowania do niepodległości. Widać w nim wyraźne nawiązania do tomistycznej interpretacji człowieka oraz nacisk na holistyczność procesów wychowawczych. Drugim istotnym zagadnieniem, na podstawie którego buduje on swój program wychowawczy, jest stawiana przez niego diagnoza współczesnego mu człowieka i sytuacji społeczno-gospodarczej na ziemiach polskich przez rokiem 1918. Połączenie tych dwóch perspektyw pozwala na zrekonstruowanie koncepcji wychowania do niepodległości Jana Ciemniewskiego.

\footnotetext{
${ }^{30}$ Tamże, s. 191.

${ }^{31}$ Tamże, s. 192-193.

${ }^{32}$ Tamże, s. 200.

${ }^{33}$ J. Ciemniewski, My, a żydzi. Przyczynek do kwestii żydowskiej, Lwów 1898, s. 189.
} 


\section{Diagnoza ówczesnego człowieka i społeczeństwa - punkt wyjścia dla rozważań o wychowaniu do niepodległości}

W swojej twórczości Jan Ciemniewski szeroko komentuje współczesne mu społeczeństwo, szczególnie zaś naród i społeczeństwo polskie, ze wskazaniem na jego podstawowe właściwości - cechy pozytywne i negatywne. Łączy to zarówno z rozważaniami o charakterze i jego wychowaniu, jak i z faktami z historii społecznej oraz gospodarczej Polski - wskazując na powiązania pomiędzy tzw. wadami narodowymi a problemami politycznymi i społecznymi, przed jakimi dawniej stała Polska, a jakie w czasach mu współczesnych mogą przeszkodzić w odrodzeniu silnej, niepodległej i wolnej Ojczyzny.

Przede wszystkim - podkreśla Jan Ciemniewski - w ówczesnym społeczeństwie coraz więcej jest ludzi rozumnych, dobrze wykształconych, ale przy tym coraz mniej porządnych i uczciwych, wyróżniających się silnym charakterem. Chociaż - jak stwierdza - poziom intelektualny większości społeczeństwa polskiego niewątpliwie podniósł się, co ocenia pozytywnie, to jednak w kwestiach moralnych - według Jana Ciemniewskiego - przestaliśmy zwracać uwagę na Boga i jego prawo. Zapanowały egoizm oraz nienawiść wobec innych ${ }^{34}$. Jak bowiem zaznacza, „kształcąc wyłącznie tylko rozum, a zaniedbując serce i wolę - pomimo całej naszej intelektualnej wyższości pod względem charakteru niżej stanęliśmy od niejednego prostaczka, który niewiele wprawdzie umie, ale silnie za to pożąda i wytrwale dąży do prawdy" ${ }^{35}$. Zatem jako do przyczyny tego problemu odwołuje się on do jednostronnego wychowania, kładzenia nacisku jedynie na wiedzę i rozwój zdolności intelektualnych - co dla niego jest ograniczaniem rozwoju człowieka. Proponuje tu zatem holistyczne podejście do wychowania człowieka (edukację każdego z elementów charakteru człowieka), krytykując wszelkie rozwiązania jednostronne jako takie, które prowadzą do negatywnych konsekwencji indywidualnych i społecznych.

Dlatego też krytykuje ów myśliciel tendencje racjonalistyczne oraz liberalne jako takie sposoby myślenia o rzeczywistości, które koncentrują swoje działanie na rozumie, niwelując wiarę i pozostawiając ludzi bez dogmatów, bez pewnego i sprawdzonego programu na życie, bez konkretnego celu, do którego mogliby dążyć. Tym samym pozostawiają one człowiekowi wolność większą niż może on unieść bez szkody dla siebie samego. Nieograniczona wolność zewnętrzna przynosi bowiem człowiekowi niewolnictwo wobec swych własnych pragnień, pożądań i namiętności ${ }^{36}{ }_{-}$

\footnotetext{
${ }^{34}$ Tamże, s. $184-185$.

${ }^{35}$ J. Ciemniewski, Poznanie i ksztatcenie charakteru, cz. I, dz. cyt., s. 11.

${ }^{36}$ Tamże, s. 12-14.
} 
instynktu i uczuć. Jak podkreśla Ciemniewski, „dzięki racyonalistom z umysłów zniknęły zasady, tak dzięki liberałom z sumień zniknęło poczucie obowiązków i powinności względem Boga i bliźniego. W ten sposób charakter pozbawiony został swej naturalnej podstawy, a ludziom grunt z pod nóg usuwać się począł" ${ }^{37}$. Tym samym wiąże te dwie perspektywy interpretacji rzeczywistości społecznej z pozostawieniem człowieka samemu sobie - co może utrudniać prawidłowy rozwój moralny i społeczny. Czyżby zatem już wtedy Jan Ciemniewski dostrzegał początki procesów związanych z zagadnieniem niepewności ponowoczesnej tożsamości, o którym rozwodzą się współcześni badacze rzeczywistości społecznej ${ }^{38}$ ?

Zarówno liberalizm, jak i racjonalizm jako krytykowane przez niego koncepcje nie są tu szczegółowo określone. Jak wiadomo pojęcia te i zjawiska będące ich desygnatami są wieloznaczne. Wydaje się, że racjonalizm określa Ciemniewski jako pewną tendencję do przypisywania rozumowi pierwszeństwa przed innymi władzami człowieka, kształcenie rozumu bez poświęcania uwagi woli oraz uczuciom, co prowadzi do lekceważenia wychowania moralnego ${ }^{39}$. Trudniej jednak określić, co Ciemniewski rozumie przez liberalizm, którego w swojej wczesnej twórczości bliżej nie opisuje. Prawdopodobnie jako osoba duchowna inspirował się on krytyką wynikającą z oficjalnych dokumentów kościelnych.

Biorąc pod uwagę dokumenty papieskie II połowy XIX wieku i początku XX wieku, można zauważyć, iż pojęcie to jest używane mało precyzyjnie, najczęściej zaś w trzech wzajemnie uzupełniających się zakresach. W pierwszym określenie liberalizmu wiąże się z ogólnie rozumianymi założeniami liberalnymi dotyczącymi wolności człowieka, indywidualizmu, utylitaryzmu, autonomii moralnej, w drugim zaś - z państwem kapitalistycznym, odwołującym się jedynie do prawa stanowionego, a nie boskiego, opartego na założeniach jak najmniejszej ingerencji we wszelkie stosunku międzyludzkie, w tym gospodarcze. W trzecim natomiast znaczeniu liberalizm, w oficjalnych dokumentach Kościoła, wiązany jest przede wszystkim z ustrojem gospodarczym, z kapitalizmem - w tym czasie głównie w jego „dzikiej” odmianie, opartej na wyzysku klas pracujących i nieograniczonej niczym rywalizacji ${ }^{40}$. Jak można sądzić, taki sam sposób interpretacji tego pojęcia stosował Jan Ciemniewski, podkreślając jednak jego konsekwencje głównie $\mathrm{w}$ odniesieniu do pierwszego $\mathrm{z}$ przedstawionych

\footnotetext{
${ }^{37}$ Tamże, s. 14 .

${ }^{38}$ Por. przykładowo prace A. Giddensa, U. Becka.

${ }^{39}$ Por. J. Ciemniewski, Poznanie i ksztalcenie charakteru, cz. I, dz. cyt., s. 11-14.

${ }^{40}$ Por. K. Chojnicka, Nauczanie społeczne Kościoła od Leona XIII do Piusa XII, Kraków 1993, s. 44-48; W. Piwowarski, ABC katolickiej nauki spolecznej, Pelplin 1993, s. 105-106.
} 
znaczeń, pewnych założeń charakterystycznych dla określanych jako liberalne sposobów rozumienia człowieka i społeczeństwa.

Pomimo negatywnej ich oceny tendencje do ulegania racjonalizmowi i liberalizmowi widzi Jan Ciemniewski przede wszystkim wśród przedstawicieli naszego narodu. Polacy skarłowacieli pod względem moralnym oraz fizycznym, a do ich głównych wad należą niedbalstwo, lekkomyślność oraz lenistwo. Brak według g niego na ziemiach polskich ludzi o takich przymiotach jak sumienność, fachowość, pracowitość, słowność, punktualność, honor ${ }^{41}$. Szczególnie punktuje on kwestie związane z brakiem pracowitości i brakiem praktycznych umiejętności zawodowych. Jak stwierdza, we współczesnym mu społeczeństwie polskim panuje przede wszystkim dyletantyzm: „wśród chłopów, rzemieślników, kupców i pedagogów przeważa typ pracownika nieobeznanego należycie ze współczesnym stanem swego zawodu, nieznającego współczesnych środków i narzędzi pracy. Brak systematyczności i gruntowności w nauce, a następnie $\mathrm{w}$ wykonywaniu zawodu, sprawia, że u nas praca tak umysłowa, jak fizyczna, jest mało wydatna mimo znacznego jej nakładu" ${ }^{2}$. Małe umiejętności związane $\mathrm{z}$ wykonywaną pracą powodują dominację zdolności czysto intelektualnych $\mathrm{z}$ pominięciem, a nawet deprecjonowaniem umiejętności praktycznych, w czym zatem znowu przejawia się racjonalizm.

Ludzie o słabej woli i nierozwiniętym rozumie (przypadłości te są konsekwencją między innymi panowania wspomnianych prądów światopoglądowych), których według Jana Ciemniewskiego jest najwięcej we współczesnym mu świecie, kierują się głównie uczuciem, które nie przemija bez pozostawienia śladu $\mathrm{w}$ psychice człowieka, a pozostawia $\mathrm{w}$ nim wyobrażenie, za pomocą którego próbuje go opanować bez udziału woli $\mathrm{i}$ rozumu ${ }^{43}$. Kierowanie się $\mathrm{w}$ swoim postępowaniu uczuciami, których człowiek nie jest w stanie kontrolować poprzez wyćwiczone odpowiednio wyższe władze $\mathrm{w}$ taki sposób, by nad nim nie zapanowały, może być niebezpieczne, zwracać go ku egoizmowi, sprzyjać skupianiu się na sobie i własnych potrzebach bardziej niż na pracy na rzecz społeczeństwa i narodu.

Przyczyn takiego upadku charakterów jednostek upatruje Jan Ciemniewski zwłaszcza $\mathrm{w}$ braku wiary oraz zaniku rodzin katolickich ${ }^{44}$ przekazujących wartości chrześcijańskie, które w najlepszy sposób pomagają człowiekowi w wypełnianiu jego pierwszorzędnego celu życiowego - osiąganiu doskonałości poprzez osobistą pracę i wysiłek. Natomiast przyczyn

\footnotetext{
${ }^{41}$ J. Ciemniewski, My, a żydzi. Przyczynek do kwestï żydowskiej, dz. cyt., s. 178-185.

${ }^{42}$ F. Bujak, Myśli o odbudowie, S.13-14, za: J. Ciemniewski, Budujmy Polskę wewnątrz, Lwów 1917, s. 25.

${ }^{43}$ J. Ciemniewski, Poznanie i ksztatcenie charakteru, cz. I, dz. cyt., s. 189-190.

${ }^{44}$ Tegoż, My, a żydzi. Przyczynek do kwestii żydowskiej, dz. cyt., s. 178.
} 
zwyrodnienia współczesnej mu kultury upatruje on przede wszystkim w upadku religii, który według niego nie może być zrekompensowany przez rozwój wiedzy i oświaty, ponieważ podstawą kształtowania charakteru jest wychowanie moralno-religijne, które Boga stawia na pierwszym planie. Współcześnie jednak większą uwagę przypisują ludzie rozwojowi umysłowemu i fizycznemu jednostki, pomijając lub ograniczając kwestie etyczne, co utrudnia im rozwój duchowy i wykształcenie silnego charakteru ${ }^{45}$. Zatem kwestie indywidualnego oraz społeczno-kulturalnego zwyrodnienia narodu polskiego są dla Ciemniewskiego ściśle powiązane ze sobą i mają te same korzenie.

Podobnie jak charakter człowieka jest wynikiem działania jednostki, tak wady oraz zalety każdego narodu wynikają z jego historii. Istnieje według Jana Ciemniewskiego charakter narodowy, powstający poprzez wielopokoleniowe nawarstwienia właściwości charakteru poszczególnych jednostek, które na przestrzeni wieków stworzyły specyficzne cechy charakterystyczne dla każdego narodu ${ }^{46}$. Naród polski jest według niego najtragiczniejszym narodem na świecie, ponieważ jego wielkie zalety przeplatają się z najgorszymi wadami: odwaga, heroizm, wspaniałomyślność, hojność, ofiarność, poszanowanie cudzych praw i świętości w historii Polski mieszają się z jego perspektywy w takich samych proporcjach z niedołężnością, brakiem umiaru, samolubstwem, zazdrością, bezrozumnością, lekkomyślnością, samowolą, nieposłuszeństwem i bezkarnością, brakiem poszanowania dla ciężkiej pracy oraz umiłowaniem wolności przenoszącym ją ponad dobro ojczyzny.

Te wady Polaków doprowadziły, według Jana Ciemniewskiego, do anarchii ducha - zarówno indywidualnego, jak i społecznego ${ }^{47}$ - zatem stały się powodem największych nieszczęść narodu polskiego na przestrzeni wieków. Odpowiedzialność za upadek Polski widział zatem w wadach naszego narodu i wynikających $\mathrm{z}$ nich błędach widocznych $\mathrm{w}$ podejmowanych decyzjach i, ogólnie rzecz biorąc, losach społeczeństwa polskiego. Jednak każdy naród według Jana Ciemniewskiego ma nie tylko swój charakter, ale pewne zadania do wypełnienia, ważne dla konkretnego społeczeństwa, ale i całej ludzkości. Za misję narodu polskiego uważa on służbę Bogu, a tym samym obronę dobra i prawdy na świecie ${ }^{48}$; do tego właśnie według niego sprowadza się podstawowy powód istnienia naszego narodu. Pojawia się tu zatem nawiązanie do kategorii mesjanistycznych.

\footnotetext{
${ }^{45}$ Tegoż, Poznanie i ksztatcenie charakteru, cz. II, Poznań 1907, s. 113-115.

${ }^{46}$ Tegoż, Poznanie i kształcenie charakteru, cz. I, dz. cyt., s. 74.

${ }^{47}$ Tegoż, Poznanie i ksztatcenie charakteru, cz. II, dz. cyt., s. 104.

${ }^{48}$ Tamże, s. 74-88.
} 
Ciemniewskie prowadzi zatem swoiste rozliczenie narodu polskiego, wskazując zarówno złe, jak i dobre strony jego istnienia i funkcjonowania na przestrzeni wieków, ale podkreślając również jego potencjalnie pozytywne funkcje w przyszłości. Człowieka mu współczesnego, Polaka oraz naród polski widzi zatem zarówno przez pryzmat jego możliwości, jak i z perspektywy słabości sprzyjającej rozpadowi naszego bytu państwowego.

Podkreśla przy tym, że na ziemiach polskich, chociaż nie tylko (jest to bowiem zjawisko coraz bardziej rozpowszechnione) brakuje ludzi o mocnym, stabilnym charakterze. Bowiem człowiek z charakterem jest najcenniejszym nabytkiem społecznym: ,jest on gwiazdą przewodnią w życiu i zapowiedzią lepszej przyszłości dla ludzi. Panując nad żądzami i popędami swymi, nikomu nie czyni on krzywdy, a spełniając wiernie obowiązki dobrego syna, męża, ojca, kupca i obywatela kraju, nie tylko przynosi pożytek, ale przykładem swoim innych pociąga do dobrego" 49 . Natomiast ludzie bez charakteru, w drugim proponowanym przez Jana Ciemniewskiego ścisłym znaczeniu, są zależni od okoliczności - wewnętrznych lub zewnętrznych, utracili według niego podstawową właściwość człowieka: umiejętność kształcenia i doskonalenia $\mathrm{się}^{50}$. A ma to poważne konsekwencje, nie tylko indywidualne, ale również społeczne: „człowiek bez charakteru - to chorągiewka na dachu, a naród, który $\mathrm{z}$ takich tylko składa się jednostek, pozbawiony jest wprost sumienia! Najpomyślniejsze warunki zewnętrzne, najpomyślniejsze losy fortuny, nie wynagrodzą zaniku charakterów w narodzie (...)" ${ }^{\text {11 }}$. Stąd też rodzi się potrzeba odpowiedniego wychowania człowieka, wpisana jest ona w jego indywidualne i społeczne funkcjonowanie.

\section{Koncepcja kształcenia charakteru Jana Ciemniewskiego jako wychowanie do niepodległości}

Jeśli ponownie przyjrzeć się wcześniejszemu ustępowi, można zauważyć, że przedstawiony sposób myślenia Jana Ciemniewskiego ma co najmniej jedną ważną implikację. Jeśli zło w narodzie polskim - odnoszące się do jego sytuacji historycznej, politycznej, społecznej oraz materialnej - utożsamione zostało $\mathrm{z}$ wadami indywidualnymi i narodowymi, które wiążą się z brakiem jednostek o silnych charakterach oraz wynikającymi $\mathrm{z}$ nich błędami, to jedynie wprowadzenie dobrej, właściwej edukacji, która doprowadzi do zmian najpierw o charakterze moralnym i duchowym, a w konsekwencji również społecznym i ekonomicznym, będzie najważniejszym czynnikiem nie tylko rozwoju jednostki czy odzyskania niepodległości przez Polskę, ale przede

\footnotetext{
${ }^{49}$ Tamże, s. 28.

${ }^{50}$ Tamże, s. 27.

${ }^{51}$ J. Ciemniewski, My, a żydzi. Przyczynek do kwestii żydowskiej, dz. cyt., s. 188.
} 
wszystkim podtrzymania niezależności, wolności oraz siły politycznej tego mającego powstać państwa. Koncepcja kształcenia charakteru Jana Ciemniewskiego jest tu propozycją czy rozwiązaniem, bynajmniej nie prostym do wprowadzenia, nie folgującym poszczególnym osobom, ich ograniczeniom, pragnieniom i popędom, ale mogącym doprowadzić w przyszłości do pełnej wolności i wielkości narodu polskiego. Jak podkreśla sam Ciemniewski, „wskazaną mamy przeto drogę do wskrzeszenia Ojczyzny. Zaczyna się ona od przeobrażania serca i odrodzenia ducha każdego z nas, a kończy się na przeobrażeniu i odrodzeniu się całego społeczeństwa" ${ }^{52}$.

Jego propozycja zmian w obszarze wychowania wychodzi od analizy współczesnej mu edukacji. Większość bowiem wad indywidualnych i narodowych oraz wynikających $\mathrm{z}$ nich problemów wiąże się według niego z funkcjonującym w Polsce systemem wychowawczym i oświatowym. Jak zauważa bowiem Ciemniewski, współczesne mu wychowanie promuje przede wszystkim spryt, zręczność, podstęp, elastyczność. Uznawanie tych cech za pożądane jest związane według niego z coraz silniej zakorzeniającym się w świadomości Polaków materializmem. Sumienie i charakter nie są niezbędne w liberalnie i materialistycznie określonej światowej karierze, co więcej, mogą nawet w niej przeszkadzać, nie są więc kształtowane przez rodziców. Wychowanie nakierowane na takie cechy sprzyja jednak zanikowi silnego charakteru wśród młodych pokoleń, rozwojowi materialistycznego podejścia do rzeczywistości oraz rozbudowywaniu postaw egoistycznych ${ }^{53}$. Drugą kwestią, którą piętnuje Ciemniewski, jest kształcenie dzieci i młodzieży, które uważa z kolei za zbyt oderwane od rzeczywistości społecznej i gospodarczej, a skupione na teoretycznym poznaniu, zamiast na umiejętnościach, które pozwalają potem dobrze i wydajnie pracować. Jak pisze, „u nas uczą dzieci z książki, stąd tyle u nas grafomanów i pseudoliteratów bez kawałka chleba, a brak coraz większy ludzi do pracy. (...) Wszystkiemu temu winno błędne wychowanie, błędne pojmowanie oświaty, identyfikowanie jej z literaturą $\mathrm{w}$ oderwaniu od życia i bez zastosowania w praktyce" ${ }^{54}$.

Pojawia się tu zatem pewna problematyczność poglądów Ciemniewskiego. Obydwie te kwestie wydają się na pierwszy rzut oka wzajemnie wykluczać: jedna krytykuje wychowanie ukierunkowane na kwestie materialistyczne, druga zaś oświatę za podejście zbyt abstrakcyjne i idealistyczne. Krytyka materializmu w wychowaniu wydaje się tak skonstruowana, że odnosić się może do zbytniego konsumpcjonizmu, a więc folgowania instynktowi i uczuciom, pozwalania im na zawładnięcie rozumem

\footnotetext{
${ }^{52}$ Tegoż, Poznanie i kształcenie charakteru, dz. cyt., s. 16.

${ }^{53}$ Tegoż, My, a żydzi. Przyczynek do kwestii żydowskiej, dz. cyt., s. 178-181.

${ }^{54}$ Tegoż, Budujmy Polskę wewnątrz, dz. cyt., 28-29.
} 
oraz wolą człowieka. Negatywna ocena abstrakcyjności i idealizmu w kształceniu wiąże się zaś $\mathrm{w}$ jego myśli ze wspomnianą już krytyką racjonalizmu jako nurtu gloryfikującego rozum przy lekceważeniu innych elementów składających się na dobry, silny charakter. Łącznikiem jest tu moralność i wynikająca z niej służba społeczeństwu jako nadrzędne zadania człowieka. W koncepcji Jana Ciemniewskiego postulaty wychowania, z jednej strony niematerialistycznego a z drugiej -praktycznego: wydają się łączyć w sposób bezkonfliktowy poprzez odniesienia do wychowania moralnego i społecznego.

Wychowanie bowiem, według Jana Ciemniewskiego, winno wdrażać do pracy, wykonywania obowiązków, dobrowolnego podejmowania trudów na rzecz nie tylko siebie samego, ale także społeczności, w której konkretna jednostka żyje. Jest możliwe tylko wtedy, gdy człowiek nie będzie szukał na ziemi „wygody i przyjemności, ale cnoty [cnót moralnych - dop. D.J.] i sprawiedliwości” chrześcijańskiej. Człowiek młody w rodzinie wychowuje się poprzez przykład - powinien być więc $\mathrm{w}$ domu przyzwyczajony do tego, by się ograniczać i kontrolować swoje popędy, ograniczać się w swoim egoizmie ${ }^{56}$, dalsza edukacja związana ze szkołą oraz samodoskonaleniem powinna być przedłużeniem procesu kształcenia charakteru, jaki odbywa się w rodzinie.

Owa postulowana przez Ciemniewskiego praktyczność wychowania z perspektywy współczesnego pedagoga wydaje się może postulatem nieco naiwnym lub bezpodstawnym, zwłaszcza w świetle ostatnich doświadczeń z tak właśnie ukierunkowaną edukacją. Dyskusja pomiędzy zwolennikami bardziej teoretycznego i bardziej praktycznego podejścia nadal trwa, ale argumenty obydwu stron wydają się kierować ich słuchacza ku myśli, że żadne z tych podejść nie jest do końca właściwe, a skupienie się tylko na jednym lub drugim nie będzie skutkować poprawą sytuacji polskiej edukacji. Pozostaje kwestia proporcji, a to ponownie jest rzecz dyskusyjna (na przykład kwestia krytyki deweyowskiego pragmatyzmu, który w założeniu ma łączyć teorię i praktykę). Należy jednak pamiętać, iż przedstawiona tu twórczość Ciemniewskiego to przełom XIX i XX wieku, a ta praktyczność kształcenia i wychowania jest mu w jego koncepcji potrzebna: po pierwsze, praca stanowi jedną z dróg osiągania doskonałości, a więc celu życiowego człowieka, dlatego powinna być wykonywana jak najlepiej - z pobudek moralnych, a nie materialistycznych; po drugie, dobrze wykonywana prowadzi do potęgi gospodarczej i militarnej narodu, do odzyskania i utrzymania niepodległości. Zatem oświata praktyczna to dla niego jeden ze sposobów wychowania do niepodległości.

\footnotetext{
${ }^{55}$ Tegoż, My, a żydzi. Przyczynek do kwestii żydowskiej, dz. cyt., s. 182.

${ }^{56}$ Tamże, s. $181-182$.
} 
Według Ciemniewskiego wychowanie wiąże się z oddziaływaniem na każdą część składową charakteru człowieka w celu takiego jej wyćwiczenia, które pozwalałoby na późniejsze samodzielne realizowanie przez konkretnego wychowanka podstawowego celu każdej osoby: samodoskonalenia się. Po pierwsze, dla ksztaltowania charakteru niezbędne jest kształcenie rozumu. Poznanie rzeczy czy idei jest ważne dla tego myśliciela, ponieważ każda wiedza rozwija i wzbogaca umysł człowieka, jednak - jak zaznacza - im wyższy przedmiot poznania, tym bardziej pozytywnie wpływa on na mądrość i cały charakter człowieka. Dlatego dla Jana Ciemniewskiego najważniejsze jest poznanie Boga - jako zwieńczenie ludzkiej wiedzy - a jednocześnie najlepszy środek do kształcenia rozumu i serca człowieka. We właściwym poznaniu Boga pomagają wiara oraz znajomość religii, stąd w czasach mu współczesnych jest ono w znacznym stopniu utrudnione ${ }^{57}$, głównie ze względu na odrzucenie religii, dokonywane przez szerzące się w świecie mu współczesnym systemy światopoglądowe.

Krytykuje on odejście od religii, wskazując jedność pomiędzy wiarą a rozumem. Jak twierdzi bowiem, „w rozumie zawarte są prawa moralne i najważniejsze zasady postępowania, na nim opiera się nauka Ewangelii Św. Cokolwiek wypływa z rozumu, nie może być przeciwnem wierze, a cokolwiek sprzeciwia się zasadom zdrowego rozsądku, nie jest i być nie może katolickiem" $" 58$. Wiara zatem wspólistnieje z poznaniem umysłowym i jest z nim nierozerwalnie związana; zachodzi tu proces współzależności pomiędzy tymi dwoma elementami. Takie podejście mocno akcentuje tomistyczne korzenie myśli Jana Ciemniewskiego, gdzie wiara i wiedza są fenomenami, które się nie wykluczają ${ }^{59}$.

Następnym elementem potrzebującym kształcenia w koncepcji Jana Ciemniewskiego jest wola, sposób ksztaltowania której z jego perspektywy jest łatwy do odgadnięcia, chociaż stwarza już trudności w realizacji. Otóż „wola ludzka jest elastyczna (...): czem więcej się od niej wymaga, byle w granicach rozsądku, tem ona więcej ze siebie wydaje i tem staje się silniejszą. Niedołęstwo zaś i kaprysy woli rosną $\mathrm{w}$ miarę ustępstw i pobłażliwości naszej”60. Zatem według Ciemniewskiego najgorszym wychowawcą jest taki pedagog, który niczego od swojego wychowanka nie wymaga, a dodatkowo pozwala na realizację wszystkich zachcianek i kaprysów. Zaś najlepszą metodą wychowawczą w przypadku woli jest przykład i oczekiwanie pracy nad sobą,

${ }^{57}$ J. Ciemniewski, Poznanie i ksztatcenie charakteru, cz. II, dz. cyt., s. 132-133.

${ }^{58}$ Tamże, s. 140.

${ }^{59}$ Por. J. Kostkiewicz, Kierunki i koncepcje pedagogiki ..., dz. cyt., s. 87-94; S. Kalka, Filozoficzna antropologia tomistyczna..., dz. cyt., s. 127-132.

${ }^{60}$ J. Ciemniewski, Poznanie i kształcenie charakteru, cz. II, dz. cyt., s. 146. 
możliwego do udźwignięcia wysiłku już od najmłodszych lat - wymogi te jednak winny być dostosowane do zdolności i siły wychowanka ${ }^{61}$.

Kształtowanie charakteru jest również potrzebne ze względu na jedno z jego podstawowych zadań, jakim jest opanowanie instynktów, wyćwiczenie umiejętności podporządkowania ich rozumowi ${ }^{62}$. Jedynie zatem ćwiczenie woli poprzez realizowanie różnych wymagań - tych zewnętrznych, ale również takich, które sam wychowanek przed sobą stawia - umożliwia kształcenie woli. Oczywiście wymagania te winny być powiązane $\mathrm{z}$ rozumowym poznaniem ludzi, świata i Boga oraz powiązane $\mathrm{z}$ opanowywaniem swoich instynktów, pożądań i namiętności.

Kształcenie charakteru to jednak dla Jana Ciemniewskiego nie tylko branie pod uwagę instynktów, woli i rozumu, ale również czwartego elementu tego złożonego fenomenu - uczuć, czyli serca. I to tej składowej przypisuje on największe znaczenie. Jak pisze, „charakter (...) zależy nie tyle od rozumu i woli, ile raczej od serca człowieka. Nie myśli i idee, ale uczucia wzniosłe tworzą bohaterów. Tylko ci ludzie dokonywują wielkich rzeczy, którzy są zdolni czuć gorąco: kochać i poświęcać się dla idei" ${ }^{63}$. Odpowiednio ukształtowane uczucie motywuje człowieka do wielkich czynów. Jednak według Ciemniewskiego kształcenie uczuć, pomimo jego wagi, jest zagadnieniem najbardziej zaniedbywanym we współczesnym mu wychowaniu, podczas gdy ta praca nad rozbudzaniem miłości wobec bliźniego powinna być powszechnym obowiązkiem. Najlepszą zaś metodą ćwiczenia kultury serca jest według tego myśliciela modlitwa, tylko bowiem łaska Boga jest $\mathrm{w}$ stanie pomóc człowiekowi w opanowaniu swoich własnych uczuć, w wyborze tych dobrych i odrzuceniu złych. Pozwala ona bowiem zrozumieć i pokochać nasz główny cel na ziemi ${ }^{64}$. Także kształcenie uczuć opiera się więc na wychowaniu religijnym i moralnym, które wyrasta tu na najważniejszą formę wychowania pozytywnie wpływającą zarówno na rozwój osobisty wychowanka, jak i rozwój całego narodu. Zatem według Jana Ciemniewskiego kształcenie charakteru obejmuje wszystkie jego elementy. Jednak myśliciel ten wskazuje nie tylko najważniejsze sposoby kształcenia rozumu, woli i uczucia - wszystkie one, ze względu na łączność z Bogiem i religią katolicką, prowadzą do samodoskonalenia $\mathrm{w}$ sferze moralnej i, za jej pośrednictwem, każdej innej.

Pokazuje również Ciemniewski obowiązki, jakie stawia przed każdym człowiekiem, każdym Polakiem, które wpajać się powinno w procesie wychowania. Te obowiązki są również czynnikami wychowawczymi

\footnotetext{
${ }^{61}$ Tamże, s. $146-162$.

${ }^{62}$ J. Ciemniewski, Poznanie i ksztatcenie charakteru, cz. I, dz. cyt., s. 54

${ }^{63}$ J. Ciemniewski, Poznanie i ksztatcenie charakteru, cz. II, dz. cyt., s. 166.

${ }^{64}$ Tamże, s. $166-170$.
} 
wpływającymi pozytywnie na kształcenie charakteru człowieka, a jednocześnie wyznaczają koncepcję wychowania do niepodległości, jaka wydaje się funkcjonować we wczesnej twórczości tego myśliciela.

Warto jednak, przed przejściem do obowiązków i jednocześnie czynników wychowawczych, zapoznać się z koncepcją ideału wychowawczego Polaka, jakiego wytworzenie stawia Jan Ciemniewski jako szczególne zadanie wychowania i kształcenia na wszystkich poziomach edukacji i we wszystkich środowiskach, chociaż szczególnie podkreśla rolę oświaty narodowej. Stara się ów myśliciel wyznaczyć ten ideał poprzez trzy przymiotniki określające jednostkę - Polaka, który ma szansę nie tylko odbudować Ojczyznę, ale również zapewnić jej świetlaną przyszłość, wielkość polityczną, społeczną i gospodarczą. Tu najlepiej widoczne jest wychowanie do niepodległości zawarte w jego koncepcji. Każda osoba realizująca w praktyce postulowany przez niego ideał wychowawczy powinna być jednostką twórczą, uspołecznioną oraz niezależną. Jednak sposób rozumienia tych określeń jest nieco inny niż narzucający się czytelnikowi współczesnemu.

Dla Ciemniewskiego jednostka twórcza to przede wszystkim osoba samodzielna i umiejąca sobie radzić w życiu. Siła twórcza to przede wszystkim umiejętności, które pozwalają jednostce zarabiać na siebie i swoje utrzymanie, a także tworzyć kapitał, który służy pośrednio także i innym (na przykład tworzenie miejsc pracy). Jednostka twórcza współtworzy dobrobyt społeczny i buduje ekonomiczną siłę swojego narodu ${ }^{65}$. Wiąże się to z odpowiedzialnością i rolą oświaty: „oświata narodowa powinna nas do tego przygotować i uzdolnić, powinna rozbudzić słabe u nas dotąd poczucie odpowiedzialności wobec społeczeństwa za każden grosz niebacznie wydany, powinna wyrobić $\mathrm{w}$ nas instynkt samozachowawczy i zmysł ekonomiczny, których tak bardzo nam brakuje" ${ }^{66}$. Jest to interesujące i bardzo praktyczne podejście do problematyki celów wychowania, jakie mogą być wyprowadzone $\mathrm{z}$ tak określonej w ideale wychowawczym właściwości człowieka.

Jednostka uspołeczniona natomiast to taka osoba, która zna i rozumie zarówno swoje prawa, jak i obowiązki, wynikające z jej przynależności do społeczności, narodu. Karnie i solidarnie współdziała $\mathrm{z}$ innymi w celu realizowania rozwoju własnego, innych członków grupy, a tym samym również - całego społeczeństwa. Interesy jednostek i różnych warstw społecznych są przez nią traktowane jako współzależne, zaś celem nadrzędnym jest dobro całego narodu ${ }^{67}$. Zatem jednostka uspołeczniona to osoba o rozwiniętym, „dobrym” patriotyzmie oraz umiejąca współpracować z innymi dla większego dobra (co oznacza również umiejętność poświęcania siebie, swoich pragnień

\footnotetext{
${ }^{65}$ J. Ciemniewski, Budujmy Polskę wewnątrz, dz. cyt., s. 19.

${ }^{66}$ Tamże, s. 35.

${ }^{67}$ Tamże, s. 19.
} 
i interesów na jego rzecz). Ostatnia cecha ideału wychowawczego Jana Ciemniewskiego to niezależność - ponownie widziana w podwójnej (choć w jego koncepcji mocno powiązanej) perspektywie: gospodarczej i niepodległościowej. Człowiek niezależny bowiem to według niego jednostka, która jest właścicielem ziemi, posiadłości, warsztatu pracy czy przedsiębiorstwa i aktywnie pracuje na rzecz ich rozwoju. Podobnie jak w przypadku twórczości - dzięki swojej niezależności wpływa pozytywnie na rozwój ekonomiczny narodu ${ }^{68}$.

Ponownie można tu zatem zobaczyć bardzo praktyczną perspektywę wyznaczania ideału wychowawczego. Jest ona jednak budowana nie z pobudek materialistycznych, ale $\mathrm{z}$ chęci zapewnienia narodowi polskiemu najpierw możliwości odzyskania niepodległości, potem zdolności przetrwania w nieprzyjaznym świecie, osiągnięcia wielkości gospodarczej, a w związku z nią również politycznej, społecznej i militarnej. Tak określony ideał wychowawczy może funkcjonować jedynie na podbudowanie moralności i etyki katolickiej, ona bowiem pozwala zachować równowagę pomiędzy praktycznymi a etycznymi kwestiami postępowania. Każe bowiem uwzględniać innego człowieka i pracować nie dla siebie (przynajmniej w mniejszym stopniu dla siebie) a dla idei dobra wspólnego.

Kwestią problematyczną pozostaje tu jednak łączenie przez Ciemniewskiego budowania potęgi gospodarczej, politycznej i militarnej narodu czy powstającego państwa polskiego z etyką katolicką. Jak się wydaje, korzeni takiego właśnie połączenia można szukać w historii narodu polskiego i silnych wpływach koncepcji mesjanistycznych $\mathrm{w}$ okresie zaborów. U Ciemniewskiego jest to widoczne $\mathrm{w}$ wyznaczaniu narodowi polskiemu specjalnej misji - służby Bogu, obrony prawdy i dobra na świecie, działaniu na rzecz odrodzenia wiary katolickiej wśród innych narodów. Tak ważna misja przyszłego państwa polskiego wydaje się uzasadniać dążenie do niepodległości, budowane za pomocą aspiracji czy czynów mających doprowadzić naród polski do wielkości nie tylko moralnej, ale również politycznej, gospodarczej i militarnej. Tylko bowiem silne państwo może w sposób efektywny wykonywać zadania wynikające z tak pojętej misji wśród innych narodów świata.

Problematyka ideału wychowawczego w koncepcji Jana Ciemniewskiego wiąże się nieodłącznie z obowiązkami każdego człowieka a jednocześnie czynnikami wychowawczymi. Pierwszym i najważniejszym krokiem do odrodzenia narodu, które osiągać można najpierw poprzez odpowiednie wychowanie a później poprzez procesy samodoskonalące, jest dbanie o zdrowie oraz kształcenie własnego temperamentu przez każdego członka narodu polskiego. Dbanie o zdrowie i życie, o indywidualny sposób

${ }^{68}$ Tamże, s. 20. 
istnienia, czucia, działania i poznawania postrzega on jako zdrowy i sprawiedliwy egoizm, przestrzeganie zasad sprawiedliwości i miłości wobec własnego organizmu, swojej fizyczności ${ }^{69}$. Człowiek musi dbać o siebie, ponieważ jest to jednym z warunków odzyskania niepodległości i budowania silnej Polski. Znowu zatem łączą się tu cele indywidualne i społeczne (narodowe).

Za jedno z podstawowych zadań każdej jednostki, a zarazem procesu wychowania, uważa również Jan Ciemniewski poznanie i uświadomienie (sobie) zobowiązań wobec swojej Ojczyzny. Jest to jeden z celów każdego narodu $^{70}$ i podstawa prowadzonego przezeń wychowania. Za podstawowy obowiązek względem narodu uznaje on tworzenie ekonomicznych podstaw jego funkcjonowania - praca stwarza dobrobyt, który dalej jest podtrzymywany przez moralność i rozwijany przez wiedzę. Tylko bowiem naród silny pod względem ekonomicznym jest narodem wolnym i niezależnym.

Według Ciemniewskiego praca dzieli się na produktywną, twórczą, ale również nieproduktywną, bierną. Co prawda każdy rodzaj pracy jest potrzebny dla funkcjonowania narodu, niemniej jednak dobra oświata powinna dążyć do tego, by jak najwięcej w danym kraju było pracowników produktywnych, twórczych, a jak najmniej biernych. Tylko taka proporcja może zapewnić dobrobyt i rozwój kraju. Oświata i prawdziwa nauka winny więc zmierzać do tego, by człowiek wykształcony nie był ciężarem dla innych, dla społeczeństwa, ale by potrafił pracować, co więcej przynosił korzyść innym członkom społeczeństwa i sam dawał zarobić osobom o mniejszych zdolnościach czy umiejętnościach. Celem wiedzy według Ciemniewskiego jest bowiem twórczość, rozumiana jako produktywność, umiejętność pracy, zdolność bycia pożytecznym dla siebie i swojego narodu. Wiedza i oświata, która człowieka odwodzi od pracy twórczej jest złem i szkodzeniem jednostce i narodowi ${ }^{71}$. Tutaj zatem przekłada Ciemniewski ideał osoby twórczej na obowiązek wobec narodu, możliwy do osiągnięcia tylko za pomocą pracy wychowawczej $\mathrm{i}$ indywidualnego wysiłku poszczególnych jednostek.

Drugą kwestią, jaką porusza Jan Ciemniewski, zaliczając ją do podstawowych obowiązków każdego człowieka i czynników kształtowania charakteru, jest moralność, rozumiana przez niego jako obowiązki człowieka odnoszące się do bliźniego. Jak zauważa, moralność dzisiaj nie jest ceniona, ludzie naprawdę etyczni są uważani za dziwaków, a toleruje się i nieraz nawet pochwala ludzi i zachowania nieetyczne. Właściwe kształtowanie charakteru

\footnotetext{
${ }^{69}$ J. Ciemniewski, Poznanie i kształcenie charakteru, cz. I, dz. cyt., s. 43.

${ }^{70}$ Tegoż, Poznanie i kształcenie charakteru, cz. II, dz. cyt., s. 30 .

${ }^{71}$ Tamże, s. 30-33.
} 
musi więc wiązać się z przywróceniem znaczenia moralności w społeczeństwie - bez tego czynnika wychowawczego ukształtowanie silnego charakteru nie jest możliwe ${ }^{72}$. Bez odrodzenia moralności nie jest możliwe również odrodzenie Polski i trwanie jej jako kraju wolnego, silnego i niezależnego. Popadniemy bowiem ponownie $\mathrm{w}$ wady narodowe, zaczniemy popełniać błędy, które ponownie doprowadzą nas do destrukcji.

Ponowny zwrot ku moralności jest zatem podstawą i warunkiem koniecznym osiągnięcia dwóch najważniejszych celów, jakie stawia Ciemniewski: indywidualnego - osiągania doskonałości i społecznonarodowego - odzyskania i utrzymania niepodległości. Jest to możliwe tylko poprzez przywrócenie ideałów prawdy, piękna i dobra, pod których wpływem następuje duchowe doskonalenie człowieka, które przekłada się praktycznie na miłość bliźniego i działanie na jego rzecz. Nie pozostaje to również bez wpływu na otoczenie. Moralność związana z tymi wartościami nie tylko „uczłowiecza”, ale również „uobywatelnia” człowieka - ideały humanitarne są bowiem bardzo blisko powiązane z narodowymi ${ }^{73}$.

Istotą $\mathrm{i}$ źródłem życia duchowego człowieka według Jana Ciemniewskiego jest bowiem miłość bliźniego. Brak miłości bliźniego jest związany z brakiem charakteru. Ciemniewski łączy ją również z miłością do wszelkich zrzeszeń ludzkich (rodzina, naród, społeczeństwo), traktując ją jako podstawę ich właściwego działania ${ }^{74}$. Dlatego tak ważne jest jej rozbudzanie w procesach wychowawczych. Według niego „wychować moralnie człowieka, to znaczy zaszczepić w jego serce wzniosłą miłość ideału, zanim skazi je niska, zmysłowa pożądliwość, a wolę wdrożyć do służby dobru i prawdzie, zanim zawładnie nią żądza cielesna. (...) Uczynić to może tylko wiara gorąca, która otwiera przed nim [wychowankiem - dop. D.J.], a przed sercem jego roztacza cudowne, nieznane mu dotąd krainy" ${ }^{\text {"5 }}$.

Problem odrodzenia moralności i edukowania w zakresie obowiązków wobec drugiego człowieka w myśli Jana Ciemniewskiego jest mocno powiązany $\mathrm{z}$ zagadnieniem religii oraz jej roli dla indywidualnego i społecznego rozwoju. Jak pisze, „religia nasza jest bezsprzecznie jednym z najpotężniejszych czynników społecznych, owszem jest początkiem wszelkiego uspołecznienia i uszlachetnienia człowieka”76. Bowiem „żyć dla Boga to znaczy żyć dla prawdy i dobra, dążyć do nich i starać się je w czyn

\footnotetext{
72 Tamże, s. 48-49.

${ }^{73}$ Tamże, s. 52-53.

${ }^{74}$ Tamże, s. 62-63.

${ }^{75}$ Tamże, s. 122.

${ }^{76}$ Tamże, s. 77.
} 
wprowadzić na każdym kroku; poświęcić się dla zapewnienia im tryumfu na świecie i założenia królestwa miłości i sprawiedliwości na ziemi”" ${ }^{\text {"7 }}$.

Dla tego myśliciela wiara i religia stanowią więc szkołę obywatelskiego współżycia narodów oraz spełniają rolę czynnika rozwoju kultury i społeczeństwa. Zagrożeniem jest zatem szerzący się ateizm, którego źródła widzi Ciemniewski nie tylko w popularnych prądach światopoglądowych, jak liberalizm lub socjalizm, ale także w błędach Kościoła. I to w Kościele i jego działalności widzi szansę na odrodzenie się wiary i religii katolickiej - pod warunkiem wprowadzenia różnego rodzaju zmian (między innymi postuluje mówienie do ludzi za pomocą języka, który potrafią oni zrozumieć, a także zmianę podręczników i metod nauczania religii) $^{78}$. To ciekawy punkt widzenia, wynikający z troski o człowieka i naród polski, nieodżegnujący się od kwestii trudnych, a starający się w sposób rzetelny pokazać wszystkie bolączki i problemy prowadzące ku rozpadowi, na podstawie których dopiero można budować propozycje zmian i rozwiązań.

Wiąże Jan Ciemniewski tę problematykę z wychowaniem w rodzinie. Jak podkreśla, podstawą chrześcijańskiego wychowania moralno-religijnego jest życie w rodzinie - w niej najpełniej może realizować się to, co jest jego istotą: życie dla Boga i dla bliźnich. Rodzina daje możliwości nauczania ofiarności i wspólnego wysiłku dla dobra wspólnoty ${ }^{79}$. Rozpoczyna ona procesy wychowania i kształcenia, które potem są kontynuowane w szkole. Według Jana Ciemniewskiego „w kierunku krzewienia i uświadamiania tych obowiązków powinna iść nauka i oświata u nas, jeżeli nie ma być jałową i bezużyteczną" ${ }^{80}$. A zatem obowiązki wobec Ojczyzny, bliźniego i wobec wiary stanowią podstawę wychowania i w myśli Jana Ciemniewskiego prowadzić mają do dwóch celów: indywidualnego - samodoskonalenia się i społecznego - odzyskania niepodległości przez Polskę. Co ważne, żaden z tych celów nie może być osiągnięty bez drugiego.

Jak się wydaje, chociaż słowo to nie pada w analizowanej twórczości Jana Ciemniewskiego, cała jego koncepcja zdaje się łączyć kwestie osobiste i indywidualne, a zaproponowany program kształcenia charakteru jest równocześnie koncepcją wychowania do niepodległości.

\section{Podsumowanie - wychowanie dla niepodległości w myśli Jana Ciemniewskiego}

Przedstawiona powyżej wczesna myśl pedagogiczna Jana Ciemniewskiego łączy wątki wychowawcze z analizą stosunków społecznych charakterystycz-

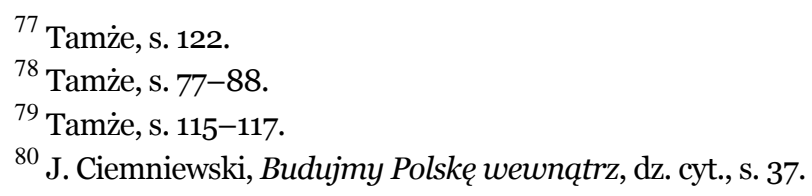


nych dla społeczeństw, zwłaszcza narodu polskiego, do roku 1918. Jest to myśl przewidująca odzyskanie niepodległości przez Polskę, ale również wskazująca warunki tego procesu, a także przesłanki do utrzymania wolności i niezależności państwa, które - jak ma nadzieję Jan Ciemniewski - wkrótce powstanie.

Odrodzenie narodu polskiego w swojej państwowości uzależnia on przede wszystkim od odnowienia moralnego jednostek, a ono możliwe jest jedynie w procesach wychowawczych i samowychowawczych. Jego szeroko rozbudowana koncepcja kształtowania charakteru (wszystkich jego elementów) ma prowadzić do odejścia od przeintelektualizowanego procesu edukacji i przyznania prymatu wychowaniu moralno-religijnemu, które zapewnić może wzrost i rozwój jednostek etycznych. Ta etyczność z jednej strony pomaga zbliżać się do Boga, z drugiej służy również najważniejszej wówczas dla narodu polskiego kwestii polityczno-społecznej - odzyskaniu niepodległości.

Oba te wątki, związane z wyznaczonymi przez Jana Ciemniewskiego celami wychowania, lączą się i przeplatają w całej branej pod uwagę twórczości tego myśliciela. Mocno ze sobą powiązane, mogą skłaniać do przyjęcia perspektywy scalającej jego koncepcje. Bowiem pomimo tego, że sam Ciemniewski nazywa swój program wychowawczy kształceniem charakteru, to jednak tak ściśle wiąże go z kwestiami społecznymi, że można tu mówić o wychowaniu do niepodległości. Wychowaniu do niepodległości rozumianym przez niego nie tylko jako narzędzie mające doprowadzić do jej odzyskania, ale przede wszystkim jako sposób mający zapewnić nowopowstającemu państwu polskiemu wolność, siłę i niezależność, które zagwarantują jego istnienie i dobrobyt na długie lata. I chociaż pewne kwestie $\mathrm{w}$ przedstawionych poglądach wydają się problematyczne $\mathrm{z}$ punktu widzenia współczesnego człowieka, to warto tu podkreślić wątki, które wydają się istotne i interesujące z punktu widzenia współczesnego pedagoga: nacisk zarówno na wychowanie, jak i na kształcenie, rozwijanie wszystkich stron osobowości wychowanka oraz łączenie rozwoju i celów wychowania, zarówno indywidualnych jak i społecznych, bez faworyzowania żadnego z nich.

Streszczenie: W niniejszym artykule podejmuję problematykę wychowania do niepodległości, która pojawia się już we wczesnych latach twórczości Jana Ciemniewskiego. W sposób szczególny koncentruję się na związkach, jakie według niego zachodzą pomiędzy wychowaniem i kształceniem człowieka a odzyskaniem przez Polskę niepodległości oraz na przedstawianym przez niego projekcie budowania wolności i wielkości mającego się odrodzić państwa.

Słowa kluczowe: kształcenie charakteru, wychowanie do niepodległości, Jan Ciemniewski, pedagogika kultury 